\title{
Právní úprava věci hromadné, souboru věcí a dopad jejich právní úpravy do praxe
}

\section{Legislation Collective Thing, Set of Things, and the Impact of Their Legislation into Practice}

\author{
Pavel Vážan ${ }^{*}$
}

\begin{abstract}
Abstrakt
Př́spèvek reaguje na pojem věci hromadné a souboru věcí, vymezení jejich vątabu s obledem na soữasné pojetí tèchto dvou pojmu a zejména pak na jejich praktické dopady ve svètle zákona c. 89/2012 Sb., občanský zákoník. Cílem prǐspèvku neni podat jednoznačnou a vyčerpávajici odpovéd’ na sporné otázky s témito pojmy souvisejicí, ale zhodnotit právni úpravu de lege lata, jeji dopad do prámí praxe a prīpadné vyvolat mo:̌né úvaby de lege ferenda.
\end{abstract}

\section{Klíčová slova}

Hromadná věc; soubor věcí; občanský zákonik.

\begin{abstract}
The paper responds to the concept of collective thing and a set of things, defining their relationship with respect to the current treatment of these two concepts and especially their practical implications in the light of Law no. 89/2012 Coll., Civil Code. Aim of this paper is not to provide a clear and comprehensive response to the issues associated with these concepts, but to evaluate the legislation de lege lata, its impact on legal practice and possibly cause possible de lege ferenda.
\end{abstract}

\section{Keywords}

Collective Thing; Set of Things; Civil Code.

\section{Úvod}

Tento př́spěvek se zabývá vymezením pojmu věci hromadné a souboru věcí, jejich vzájemného vztahu, odlišností a dopadem jejich právní úpravy, ve světle zákona č. 89/2012 Sb., občanský zákoník (dále jen „ObčZ“), do právní praxe. Jako autor tohoto príspěvku si nekladu za cíl podat jednoznačné a vyčerpávající odpovědi na sporné otázky, které s těmito pojmy souvisí; tyto přinese až př́ípadná judikatura, resp. změna právní úpravy. Cílem př́spěvku je zhodnotit právní úpravu de lege lata a př́padně vyvolat možné úvahy de lege feren$d a$. V souladu s dosavadní relevantní judikaturou, zastávanými názory a stanovisky se $\mathrm{v}$ př́spěvku pokouším právní úpravu věci hromadné a souboru věcí interpretovat, zhodnotit a př́padně poukázat na její nedostatky s ohledem na praktické potřeby právní praxe.

\footnotetext{
* Mgr. Bc. Pavel Vážan, doktorand, Katedra občanského práva, Právnická fakulta Masarykovy univerzity, Brno / Ph.D. student, Department of Civil Law, Faculty of Law, Masaryk University, Brno, Czech Republic / E-mail: pavel.vazan@seznam.cz
} 
K problematice věci hromadné a souboru věcí, vymezení jejich vzájemného vztahu a odlišností již bylo pojednáno řadou autorů v odborné literatuře i relevantních publikacích. K danému tématu lze nalézt i širokou škálu judikovaných závěrů a postojů soudů. Definici věci hromadné zakotvoval již zákon č. 946/1811 Sb. zák. soud., obecný zákoník občanský (dále jen „OZO“) a komentářová literatura k tomuto zákonu ${ }^{1}$ se pokoušela pojem hromadné věci více či méně osvětlit. Nutno podotknout, že zákon č. 141/1950 Sb., občanský zákoník (dále jen „ObčZ 1950“) ani zákon č. 40/1964 Sb., občanský zákoník (dále jen „ObčZ 1964“) věc hromadnou ani soubor věcí nedefinovali. ${ }^{2}$ Nicméně ani přijetím ObčZ, který výslovně vymezuje pouze věc hromadnou (nikoli však již soubor věcî), se nepodařilo odstranit veškeré sporné otázky, které s věcí hromadnou a souborem věcí souvisejí. Pro správné pojetí věci hromadné a souboru věcí je nezbytné vymezit jejich obsah a určit jejich vzájemný vztah ve světle právní úpravy ObčZ (především absolutních majetkových práv) a souvisejících právních předpisů.

\section{Věc hromadná, její vymezení}

Věc hromadnou (universitas rerum) ${ }^{3}$ definoval již ve svém ustanovení \302 OZO, podle kterého platilo: „Úhrn několika věcí jednotlivých, který se za věc jednu považuje a bývá označován společným jménem, tvoří věc hromadnou a pokládá se za celek. “4 Komentářová literatura k tomuto ustanovení OZO podávala výklad, že v př́padě věci hromadné jde o právní skutečnost, kdy několik (jednotlivých) věcí tvoří celek; tyto jednotlivé věci navíc musí být ve vlastnictví toho, kdo je vlastníkem (resp. pánem) věci hromadné. ${ }^{5}$ Ve smyslu ustanovení \302 OZO se tedy hromadná věc vyznačovala těmito znaky:

a) úhrn několika jednotlivých věcí;

b) tento se považuje za jednu věc;

c) a bývá označován společným jménem.

1 Mezi stěžejní můžeme zařadit publikaci SEDLÁČEK, Jaromír, ROUČEK, František. Komentár k Céeskoslovenskému obecnému zákoníku ob̌́anskému a občanské právo platné na Slovensku a v Podkarpatské Rusi. Díl druby ( 285 aそ̌ 530). Praha: Právnické knihkupectví a nakladatelství V. Linhart, 1935. Reprint původního vydání CODEX Bohemia, s. r. o., 1998, 970 s. ISBN 80-85963-64-7.

2 Výslovné zákonné vymezení hromadné věci v ObčZ 1950 a ObčZ 1964 chybělo. Ustanovení \$153 ObčZ 1964 pouze hovořilo o tom, že zástavou může být mimo jiné „podnik nebo jiná věc hromadná“ a „soubor věci“". Za věc hromadnou byl výslovně označen pouze podnik, a to podle ustanovení \5 odst. 2 věty první zákona č. 513/1992 Sb., obchodní zákoník: „Podnik je věc bromadnä“. V ostatních př́padech, bylo nutné vyjít ze znaků věci hromadné definovaných doktrínou a judikaturou, př́padně se inspirovat právní úpravou OZO.

3 \302 zákona č. 946/1811 Sb. zák. soud., obecný zákoník občanský.

4 Srov. rozhodnutí Nejvyššího soudu Československé republiky Rv I 1139/24 ze dne 06. 08. 1924: „Podle

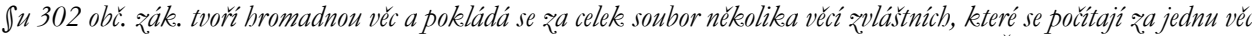
a označuji se společným jménem. "In: ASPI [právní informační systém]. Wolters Kluwer ČR [cit. 05. 03. 2016].

5 SEDLÁČEK, Jaromír, ROUČEK, František. Komentár k Céskoslovenskému obecnému zákoníku obéanskému a občanské právo platné na Slovensku a v Podkarpatské Rusi. Díl drubý (\$ 285 až 530). Praha: Právnické knihkupectví a nakladatelství V. Linhart, 1935. Reprint původního vydání CODEX Bohemia, s. r. o., 1998, s. 56. ISBN 80-85963-64-7. 
Úhrn několika jednotlivých věcí byl považován za jednu věc podle názoru obchodu hlediska objektivního, nikoli podle názoru jednotlivce - hlediska subjektivního. ${ }^{6}$

Jelikož ObčZ 1950 ani ObčZ 1964 definici věci hromadné neobsahovaly, bylo vymezení obsahu tohoto pojmu více méně závislé na doktríně a judikatuře soudů, kdy ve většině př́padů bylo odkazováno právě na úpravu ustanovení \302 OZO.

Ustanovení \501 ObčZ, podobně jako \302 OZO, stanovuje, že: „,Soubor jednotlivých věci nále žejicich téže osobè, považovaný za jeden predmèt a jako takový nesouci společné označeni, pokládá se za celek a tvoř́ hromadnou věc. " Z definice hromadné věci podle ustanovení \501 ObčZ můžeme dojít k závěru, že pro označení věci za věc hromadnou, musí být kumulativně splněny následující 4 pojmové znaky:

a) musí jít o soubor (2 a více) jednotlivých věcí;

b) musí náležet téže osobě (vlastníkovi);

c) musí být považovaný za jeden předmět;

d) a musí nést společné označení. ${ }^{8}$

Na rozdíl od ustanovení \302 OZO, tak ustanovení \501 ObčZ navíc výslovně uvádí, jako jeden z pojmových znaků věci hromadné, že musí jít o soubor jednotlivých věcí náležejících téže osobě.

Pokud tedy dojde ke kumulativnímu naplnění shora uvedených pojmových znaků (podmínek), bude možné daný soubor jednotlivých věcí považovat za celek, resp. věc hromadnou ve smyslu \501 ObčZ. Ustanovení \501 ObčZ je v souladu s \ 1 odst. 1 ObčZ ustanovením kogentním; nikoli však absolutně, ale pouze co se týče vymezení pojmových znaků, při jejichž naplnění je možné soubor jednotlivých věcí označit za hromadnou věc. S ohledem na podstatu a účel věci hromadné, kdy tento institut soukromého práva slouží především ke zjednodušení právního styku, ${ }^{9}$ není možné dojít k závěru, že pokud budou naplněny pojmové znaky ustanovení \501 ObčZ, bude soubor jednotlivých věcí vždy automaticky považován za věc hromadnou a jako s věcí hromadnou s ním bude i dále nakládáno. Z tohoto úhlu pohledu musíme ustanovení \501 ObčZ považovat za dispozitivní a bude záležet (pouze) na vưli vlastníka jednotlivých věcí, které splňují podmínky ustanovení \501 ObčZ, zda s nimi bude nakládat jako s věcí hromadnou či nikoli.

6 SEDLÁČEK, Jaromír, ROUČEK, František. Komentár k Československému obecnému zákoníku občanskému a obćanské právo platné na Slovensku a v Podkarpatské Rusi. Dil drubý (\$285 ą̌ 530). Praha: Právnické knihkupectví a nakladatelství V. Linhart, 1935. Reprint původního vydání CODEX Bohemia, s. r. o., 1998, s. 56. ISBN 80-85963-64-7.

7 Srov. Rozhodnutí Městského soudu v Praze ze dne 1. 4. 2010, sp. zn. 177 Cm 4/2009.

8 Srov. MELZER, Filip, TÉGL, Petr a kol. Občanský zákonik - velký komentár. Svazek III., \419-654. Praha: Leges, 2014, s. 282. ISBN 978-80-7502-003-1.

9 ŠVESTKA, Jiří, DVOŘÁK, Jan, FIALA, Josef a kol. Občanský zákoník. Komentár. Svazeke I. Praha: Wolters Kluwer, a. s., 2014, s. 1182. ISBN 978-80-7478-370-8. 
Hodnocení, resp. posouzení, zda jsou v konkrétním případě jednotlivé pojmové znaky věci hromadné naplněny, může být, s ohledem dikci ustanovení \501 ObčZ, v praxi poněkud problematické a činit větší či menší potíže. Domnívám se, že pouze podmínka uvedená pod písm. b), tedy že soubor jednotlivých věcí musí náležet téže osobě, nebude $\mathrm{v}$ praxi činit větších (interpretačních ani aplikačních) problémů, vyjma případu spoluvlastnictví a společného jmění. Ne tak zcela jasná je však formulace podmínek uvedených pod písm. a), c) a d). Při interpretaci ustanovení \501 ObčZ považuji za vhodné vyjít (alespoň částečně) z dosavadní judikatury, doktríny a zastávaných názorů, s ohledem na podstatu a účel institutu věci hromadné ve světle ObčZ.

\subsection{Podmínka písm. a)}

První z podmínek, pro označení souboru věcí za věc hromadnou podle $\int 501$ ObčZ, stanoví, že musí jít o ,soubor jednotlivých věcl" ${ }^{*}{ }^{10}$

Ustanovení \ 501 ObčZ do určité míry přebírá definici věci hromadné z ustanovení \ 302 OZO. Použití slovního spojení „soubor jednotlivých věcǐ v definici věci hromadné dle \501 ObčZ nepovažuji za vhodné, jelikož soubor věcí, jak bude pojednáno níže v textu, je nutné ve světle ObčZ a souvisejících právních předpisů považovat za pojem, resp. konstrukci, která je zcela odlišná od pojmu věci hromadné. Na rozdíl od souboru věcí, je věc hromadná považována za jeden předmět právních vztahů a její definice je v ObčZ výslovně zakotvena, zatímco soubor věcí v ObčZ definován není. ${ }^{11} \mathrm{~V}$ této souvislosti pak může být použití slovního spojení „soubor jednotlivých věct $\mathrm{v}$ definici věci hromadné zavádějící a $\mathrm{v}$ praxi působit komplikace př́i určení, zda $\mathrm{v}$ konkrétním př́padě jde o věc hromadnou, či nikoli. Cílem zákonodárce bylo vyjádřit, že určité množství, kvantum, či souhrn předmětů, resp. věcí, ${ }^{12}$ lze při splnění dalších podmínek ustanovení \501 ObčZ považovat za hromadnou věc, tedy jeden celek. Definice věci hromadné podle ustanovení \302 OZO je v tomto směru méně zavádějící; pro označení věcí tvořících jeden celek (věc hromadnou), používá \302 OZO, na rozdíl od ustanovení \501 ObčZ, nikoli pojem ,soubor“, ale pojem „úhrn“. ${ }^{13}$ De lege ferenda považuji za vhodné přizpůsobit tomuto dikci ustanovení \501 ObčZ; namísto pojmu „soubor“ použít jiný pojem vyjadřující určité kvantum jednotlivých věcí, např. pojem „úhrn“, který používal OZO.

Z formulace ustanovení $\int 501$ ObčZ, podmínky písm. a), nicméně jednoznačně vyplývá, že musí jít o soubor (úhrn či množinu) jednotlivých věcí, který je složen alespoň ze dvou jednotlivých (samostatných) věcí. ${ }^{14}$ Pozitivní vymezení věci v právním smyslu

10 Zákon č. 89/2012 Sb., občanský zákoník.

11 Je však nutné dodat, že i přes absenci definice souboru věcí v ObčZ, se např̀. v ustanovení \ 1887 ObčZ hovoří o postoupení souboru pohledávek.

12 ŠVESTKA, Jiří, DVOŘÁK, Jan, FIALA, Josef a kol. Občanský zákoník. Komentár. Svažek I. Praha: Wolters Kluwer, a. s., 2014, s. 1182. ISBN 978-80-7478-370-8.

13 Zákon č. 946/1811 Sb. zák. soud., obecný zákoník občanský.

14 Srov. MELZER, Filip, TÉGL, Petr a kol. Občanský zákoník - velký komentár. Svazek III., \419-654. Praha: Leges, 2014, s. 282. ISBN 978-80-7502-003-1. 
obsahuje ustanovení \489 ObčZ, podle kterého: „Věc v právním smyslu (dále jen „věc“) je vše, co je rozdílné od osoby a slouři potřebě lidí." Jak uvedl prof. Dr. JUDr. Karel Eliáš, věc jednotlivá se od věci hromadné liší tím, že věc hromadná je tvořena více věcmi jednotlivými. ${ }^{15}$ Věci v právním smyslu můžeme dále dělit (tř́idit), a to podle různých kritérií, nap̌r. na věci: a) hmotné a nehmotné, b) ovladatelné př́rodní síly, c) nemovité a movité, d) zastupitelné a nezastupitelné, e) zuživatelné a nezuživatelné, f) hromadné, g) obchodní závod a pobočku, h) obchodní tajemství, ${ }^{16}$ i) individuálně a genericky určené, ${ }^{17}$ j) reálně dělitelné a nedělitelné. ${ }^{18}$ \ 501 ObčZ však pouze obecně stanovuje, že hromadnou věc může (za předpokladu splnění všech ostatních podmínek \501 ObčZ) tvořit soubor jednotlivých „věcí“, bez jejich další (bližšî) specifikace. Vyvstává tedy otázka, jaké věci v právním smyslu mohou fakticky věc hromadnou tvořit, resp. zda existuje určitý druh věcí, které věc hromadnou tvořit nemohou, prríp. které za věc hromadnou označit nelze. Žrejmě nebudou nevznikat pochyby o tom, že věc hromadnou mohou tvořit jednotlivé (individuálnî) věci hmotné (např. vodovodní řad a vodárenské objekty tvořící vodovod ve smyslu zákona o vodovodech a kanalizacích, jako věc hromadnou ${ }^{19}$ ), nehmotné (např. zaknihované cenné papíry ${ }^{20}$ ), movité (např. poštovní známky tvořící sbírku známek, jako věc hromadnou ${ }^{21}$ ), nemovité (např. komplex vinných sklepů, jakožto podzemních staveb se samostatným účelovým určením), a dále i věci zastupitelné, nezastupitelné, zuživatelné, nezuživatelné, reálně dělitelné i nedělitelné. Věc hromadná však nemusí být vždy tvořena jen souborem jednotlivých věcí stejného druhu, např. jen věcmi movitými apod. Věc hromadná může být tvořena i souborem jednotlivých věcí hmotných, nehmotných, movitých i nemovitých, tedy souborem jednotlivých věcí různého druhu; typickým př́kladem takové hromadné věci bude obchodní závod ${ }^{22}$ nebo pozůstalost ${ }^{23}$.

15 ELIÁŠ, Karel. Věc jako pojem soukromého práva. Právní rozhledy 4/2007, s. 119.

16 \496 - \504 zákona č. 89/2012 Sb., občanský zákoník.

17 KNAPPOVÁ, Marta, ŠVESTKA, Jiří, DVOŘÁK, Jan a kol. Občanské právo bmotné 1. Díl pruni: Obecná část. Díl drubý: Věcná práva. 4. aktualizované a doplněné vyd. Praha: ASPI, a. s., 2005, s. 277. ISBN 80-7357-127-7.

18 Tamtéž, s. 278.

19 Rozsudek Nejvyššího soudu ČR ze dne 10. prosince 2009, sp. zn. 22 Cdo 944/2007.

20 MELZER, Filip, TÉGL, Petr a kol. Občanský zákoník - velký komentár. Svaz̨ek III., \419-654. Praha: Leges, 2014, s. 283. ISBN 978-80-7502-003-1.

21 Rozsudek Nejvyššího soudu ČR ze dne 24. dubna 2012, sp. zn. 4 Tdo 383/2012-50.

$22 \mathrm{Na}$ rozdíl od podniku, který byl za věc hromadnou výslovně označen v ustanovení \5 odst. 2 větě první zákona č. 513/1992 Sb., obchodní zákoník, není obchodní závod v ObčZ za věc hromadnou výslovně označen. Nicméně v dosavadní praxi nevznikají pochybnosti o tom, že obchodní závod naplňuje znaky ustanovení S 501 ObčZ; tento závěr vyplývá i z dưvodové zprávy k ObčZ, a dále z komentářové literatury k ObčZ (srov. např. MELZER, Filip, TÉGL, Petr a kol. Občanský qákoník - velký komentár. Svazek III., $\int$ 419-654. Praha: Leges, 2014, s. 283. ISBN 978-80-7502-003-1; nebo SPÁČIL, Jiří a kol. Občanský zákoník. I. Obecná cást (』 1-654). Komentár. 1. vyd. Praha: C. H. Beck, 2013, s. 2380. ISBN 978-80-7400-529-9).

23 SPÁČIL, Jiř́i a kol. Občanský zákoník I. Obecná část (』 1-654). Komentár. 1. vyd. Praha: C. H. Beck, 2013, s. 1773. ISBN 978-80-7400-529-9. 
Do jisté míry problematickou bych viděl kategorii věcí genericky (druhově) určených. Domnívám se, že nelze bez dalšího souhlasit s názorem JUDr. Kindla, podle kterého se hromadnou věcí rozumí i neurčité kvantum, skládající se z mnoha kusů, které samy o sobě žádnou hodnotu nemají a hodnoty nabývá až určitá kvantita těchto kusů (jako př́klad uvádí tunu písku či štěrku nebo tunu obilí, apod.). ${ }^{24}$ Toto neurčité kvantum mnoha kusů, které samy o sobě žádnou hodnotu nemají, mohou reprezentovat právě věci genericky (druhově) určené a jako takové je neurčité pouze relativně, jelikož věci genericky určené se vyznačují druhovými znaky, jako je míra, váha nebo počet. ${ }^{25}$ Dr Rouček v komentáři k ustanovení \ 294 OZO podává výklad, že jednotlivá věc může být složena z několika kusů, které samy o sobě nejsou „úkojnými prostředky“ (jako příklad uvádí zrnko písku nebo obilî); za „úkojný prostředek“ považuje až určitou kvantitu těchto kusů. ${ }^{26} \mathrm{Na}$ rozdíl od JUDr. Kindla, však Dr Rouček tento typ (genericky) určených věcí považuje stále za věci jednotlivé (individuálně určené), které odlišuje od věci hromadné. ${ }^{27}$ Osobně považuji za správný názor Dr Roučka a domnívám se, že s ohledem na účel a podstatu věci hromadné, nelze věc genericky určenou bez dalšího považovat za věc hromadnou, resp. dokonce dojít k závěru, že každá věc genericky určená je ve smyslu ustanovení \501 ObčZ zároveň věcí hromadnou. Podstata institutu věci hromadné spočívá v tom, že se na daný soubor jednotlivých věcí fikcí zákona pohlíží jako na jedinou věc, ${ }^{28}$ pro množinu jednotlivých věcí je stanoven jednotný právní režim. ${ }^{29} \mathrm{Na}$ věc genericky určenou se ovšem také pohlíží jako na věc jedinou, která je specifikována druhovými znaky, a tak je s ní i nakládáno. Dovolím si tedy tvrdit, že označení genericky určené věci za věc hromadnou samo o sobě postrádá jakýkoliv smysl a nenaplňuje podstatu a účel institutu věci hromadné. $\mathrm{Na}$ druhou stranu je zapotřebí dodat, že i věc genericky určená, může s jinými jednotlivými věcmi (at' už individuálně nebo genericky určenými) naplňovat znaky \501 ObčZ a ve svém úhrnu tak tvořit věc hromadnou.

V souvislosti s věcí hromadnou stojí za zvláštní pozornost úvahy týkající se součásti a příslušenství věci. $V$ př́padě, že budeme posuzovat, zda jedna věc hlavní (např. pozemek) a její součásti (např. stavby, které jsou součástí tohoto pozemku) naplňují znaky

24 KINDL In: ŠVESTKA, Jiř́;,DVOŘÁK, Jan, FIALA, Josef a kol. Občanský zákoník. Komentář. Svazek I. Praha: Wolters Kluwer, a. s., 2014, s. 1182. ISBN 978-80-7478-370-8.

25 ELIÁŠ, Karel. Věc jako pojem soukromého práva. Prární roz̧hledy, 4/2007, s. 119.

26 SEDLÁČEK, Jaromír, ROUČEK, František. Komentár k Československému obecnému zákoníku občanskému a občanské právo platné na Slovensku a v Podkarpatské Rusi. Dil drubý (』 285 až 530). Praha: Právnické knihkupectví a nakladatelství V. Linhart, 1935. Reprint původního vydání CODEX Bohemia, s. r. o., 1998, s. 30 ISBN 80-85963-64-7.

27 Tamtéž, s.56.

28 ŠVESTKA, Jiří, DVOŘÁK, Jan, FIALA, Josef a kol. Občanský zákoník. Komentár. Svaz̧ek I. Praha: Wolters Kluwer, a. s., 2014, s. 1182. ISBN 978-80-7478-370-8.

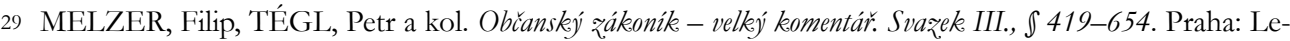
ges, 2014, s. 282. ISBN 978-80-7502-003-1. 
věci hromadné, se domnívám, že nikoli. Dikce ustanovení \501 ObčZ jednoznačně předpokládá existenci alespoň dvou věcí jednotlivých, což v př́padě jedné věci hlavní a jejích součástí splněno není. Součást věci za jednotlivou věc považovat nelze. Pokud ale více jednotlivých věcí hlavních kumulativně naplní podmínky \501 ObčZ, bude možné je považovat za hromadnou věc, a to včetně jejich součástí; z praktického hlediska je však nutné vnímat i tu skutečnost, že součást věci hlavní bude vždy sledovat její osud. ${ }^{30}$ Co se týče příslušenství věci, není možné jedinou věc hlavní a její př́slušenství, stejně jako jedinou věc hlavní a její součásti, považovat za věc hromadnou. Opačný názor zastává JUDr. Tégl, podle kterého i jediná věc hlavní spolu s jejím prríslušenstvím může tvořit věc hromadnou (jako př́klad uvádí pozemek a něm stojící stavby, které s pozemkem hospodářky souvisî). ${ }^{31}$ Ustanovení \510 odst. 1, věta první, ObčZ stanoví, že: „Př̀slušenství věci je vedlejšsi věc vlastníka u věci hlavni, je-li účelem vedlejš̀ věci, aby se ji trvale ư̌ivalo společnè s hlavni véci v rámci jejich hospodárskébo určeni." ObčZ tedy výslovně počítá s tím, že příslušenství věci hospodářsky souvisí s věcí hlavní. Nadto ustanovení $\int 510$ odst. 2 ObčZ zakotvuje vyvratitelnou právní domněnku, podle které platí, že: „Má se za to, že se právni jednáni a práva i povinnosti týkajici se hlavni věci týkaji i jejího prǒslušenstvi." \510 ObčZ je ustanovením kogentním; objektivně stanovuje, co se považuje za př́slušenství věci hlavní. Pokud tedy v konkrétním případě dojde k naplnění pojmových znaků \510 ObčZ, bude vedlejší věc vlastníka u věci hlavní považována za př́slušenství věci hlavní (pozemek bude představovat věc hlavní a stavby na tomto pozemku stojící jeho příslušenstvî). V souvislosti s věcí hlavní pak tato věc vedlejší nemůže být považována za samostatnou (jednotlivou) věc. V tomto směru je naopak ustanovení \501 ObčZ dispozitivní a záleží na vůli vlastníka, zda při splnění podmínek \501 ObčZ bude soubor jednotlivých věcí považovat za věc hromadnou či nikoli. S ohledem na (kogentnî) povahu ustanovení \510 ObčZ nelze jedinou věc hlavní a její př́íslušenství zároveň označit za věc hromadnou; $v$ takovém případě totiž podmínka písm. a) splněna nebude. Není pochyb o tom, že soubor více jednotlivých věcí hlavních může, včetně jejich príslušenství, tvořit hromadnou věc. Nadto se domnívám, že příslušenství jediné věci hlavní může podmínky \510 ObčZ naplnit a ve svém souhrnu tak tvořit hromadnou věc; v praxi tedy může nastat situace, kdy příslušenství jediné věci hlavní bude zároveň možné označit za hromadnou věc (např. hotelový jídelní servis může být vnímán jako prríslušenství hotelu - věci hlavní; sám o sobě však může být považován za hromadnou věc).

\subsection{Podmínka písm. b)}

Možné diskuze by u podmínky písm. b), tedy že soubor jednotlivých věcí „musí náležet téže osobě (vlastnikovi)“, mohla vyvolat otázka týkající se spoluvlastnictví a společného

30 Praktický dopad viz ustanovení $₫ 1347$ ObčZ.

31 TÉGL In: MELZER, Filip, TÉGL, Petr a kol. Občanský zákoník - velký komentár. Svazek III., $\int 419-654$. Praha: Leges, 2014, s. 282. ISBN 978-80-7502-003-1. 
jmění. \1115 odst. 1 ObčZ stanoví, že: „Osoby, jimž náleží vlastnické právo ke věci společně, jsou spoluvlastnikey.“; z \1116 ObčZ vyplývá, že: „V z̧hledem ke věci jako celku, se spoluvlastníci pova ̌̌uji za jedinou osobu a nakládaji s vécí jako jediná osoba." Podle \ 708 odst. 1 ObčZ, věty první, dále platí, že: „To, co manželìm nále ṛ̌, má majetkovou hodnotu a neni vyloučeno zprávních pomèrù, je součásti společného jmèni manželui (dále jen „společné jmèni“)." Společné jmění podléhá režimu zákonnému, smluvenému, anebo režimu založenému rozhodnutím soudu. ${ }^{32}$ U všech tří režimů, kterým může společné jmění podléhat, obsahuje ObčZ v ustanovení \ 709 a násl. obecná pravidla správy. Jak již bylo řečeno, institut věci hromadné slouží především ke zjednodušení obchodu, resp. ke zjednodušení nakládání s kvantem věcí určité kvality. ${ }^{33}$ Lze tedy konstatovat, že spoluvlastnictví ani společné jmění by nemělo jít k tíži ustanovení \501 ObčZ, v obecné rovině by nemělo představovat překážku pro splnění podmínek ustanovení \501 ObčZ a v praxi tak věc hromadná může být ve spoluvlastnictví více osob, případně může být součástí společného jmění.

Jestliže ovšem nastane př́pad, kdy alespoň u jednoho spoluvlastníka nebudou jeho spoluvlastnické podíly ke všem jednotlivým věcem stejné, bude pro další možné nakládání s věcí hromadnou ve spoluvlastnictví nutné, aby (všichni) spoluvlastníci jednotlivých věcí na základě dohody upravili, resp. určili, své spoluvlastnické podíly vzhledem k věci hromadné. ${ }^{34}$

Otázkou pak zůstává, jak přistupovat k situaci, kdy se spoluvlastníci, resp. manželé, neshodnou na tom, zda s jednotlivými věcmi, při splnění podmínek ustanovení \501 ObčZ, nakládat jako s věcí hromadnou či nikoli. Je zcela nepochybné, že v určitých př́ipadech může být výhodnější nakládat se souborem jednotlivých věcí jako s věcí hromadnou, a to nejen z ekonomického hlediska. Mám za to, že v takovém př́padě bude zapotřebí vyjít z ustanovení \1126 a násl. ObčZ, upravujících správu společné věci, a ustanovení \ 709 a násl. ObčZ, upravujících správu majetku ve společném jmění.

\subsection{Podmínka písm. c)}

Z hlediska interpretace a následné aplikace ustanovení \501 ObčZ může činit jisté problémy zejména podmínka písm. c), podle které soubor věcí náležejících téže osobě „musí být považovaný za jeden prédmèt".

32 \ 708 odst. 2 zákona č. 89/2012 Sb., občanský zákoník. In: ASPI [právní informační systém]. Wolters Kluwer ČR [cit. 14. 03. 2016].

33 ŠVESTKA, Jiř́, DVOŘÁK, Jan, FIALA, Josef a kol. Občanský zákonik. Komentár. Svazek I. Praha: Wolters Kluwer, a. s., 2014, s. 1182. ISBN 978-80-7478-370-8.

34 Tato situace nenastane $\mathrm{v}$ př́padě, kdy spoluvlastnické podíly všech spoluvlastníků ke všem jednotlivým věcem jsou stejné; tedy nap̌̌. v situaci, kdy každý spoluvlastník vlastní spoluvlastnický podíl o velikosti id. $1 / 4$ každé jednotlivé věci. $V$ takovém prípadě bude spoluvlastnický podíl každého spoluvlastníka $k$ věci hromadné o velikosti id. $1 / 4$. Nicméně je třeba dodat, že i v tomto př́padě přichází v úvahu dohoda jednotlivých spoluvlastníků, na základě které si velikost svých spoluvlastnických podílů $\mathrm{k}$ věci hromadné upraví odlišně od velikosti jejich spoluvlastnických podílů $\mathrm{k}$ jednotlivým věcem. 
Původní formulace této podmínky podle ustanovení \302 OZO zněla: „...které se za věc jednu považují..."; Dr Rouček k této podmínce dále uvádí, že u věci hromadné jde o př́ipad, kdy věci tvoří věc, a to podle názorů obchodu, nikoli jednotlivce $;^{35} \mathrm{z}$ toho vyplývá, že jde o kritérium objektivní, nikoli subjektivní. Podle ustanovení \501 ObčZ podmínka písm. c) zní: „...považovaný za jeden prédmět...“. Stejně jako ustanovení \302 OZO, je i ustanovení \501 ObčZ zapotřebí interpretovat tak, že soubor jednotlivých věcí musí být považovaný za jeden předmět z hlediska objektivního; nikoli pouze na základě vưle vlastníka jednotlivých věcí nebo na základě shodné vưle stran právního jednání, jehož předmětem takový soubor jednotlivých věcí je.

Objektivní kritérium stanovené podmínkou písm. c) ustanovení \501 ObčZ je základním předpokladem pro to, aby se jednotlivé věci dali označit za věc hromadnou a takto s nimi bylo i dále nakládáno. Je důležité si však uvědomit, že soubor jednotlivých věcí musí být objektivně považován za jeden předmět sám o sobě, nikoli až v souvislosti s jinou právní skutečností (např. se zápisem zástavního práva k souboru jednotlivých věcí, coby věci hromadné, do Rejstř́ḱ zástav).

Mezi určující kritéria, podle kterých lze z objektivního hlediska soubor jednotlivých věcí považovat za věc hromadnou, lze zařadit především hospodářskou souvislost a funkčnost $^{36}$ jednotlivých věcí, jejich vnitřní spojenî ${ }^{37}$ a jejich jednotný účel ${ }^{38}$.

\subsection{Podmínka písm. d)}

Poslední shora uvedená podmínka písm. d), stanoví, že soubor jednotlivých věcí „musí nést společné označeni". Soubor jednotlivých věcí je tedy označen pojmem, který věc hromadnou vymezuje, charakterizuje a ve své podstatě určuje i její předmět ve vztahu k jednotlivým věcem, které ji tvoří. Jak uvádí JUDr. Koukal, jde o abstrakci, při které se jednotlivé prvky celku označují jediným společným pojmem. ${ }^{39}$ Význam věci hromadné se v této souvislosti vyčerpává tím, že pro jednotlivé věci je použito souborného označení; tyto bez nutnosti jejich individuálního výčtu sledují společný právní osud. ${ }^{40}$

35 SEDLÁČEK, Jaromír, ROUČEK, František. Komentár k Československému obecnému zákoníku občanskému a občanské právo platné na Slovensku a v Podkarpatské Rusi. Díl drubý (』 285 aそ̌. 530). Praha: Právnické knihkupectví a nakladatelství V. Linhart, 1935. Reprint původního vydání CODEX Bohemia, s. r. o., 1998, s. 56. ISBN 80-85963-64-7.

36 TÉGL In: MELZER, Filip, TÉGL, Petr a kol. Obcanský zákoník - velký komentár. Svazek III., $\int 419-654$. Praha: Leges, 2014, s. 284. ISBN 978-80-7502-003-1.

37 SPÁČIL, Jiří a kol. Občanský zákonike I. Obecná cást (』 1-654). Komentár. 1. vyd. Praha: C. H. Beck, 2013, s. 1773. ISBN 978-80-7400-499-5.

38 ELIÁŠ, Karel. Věc jako pojem soukromého práva. Právní roz̧bledy, 4/2007, s. 119.

39 KOUKAL In: SPÁČIL, Jiří a kol. Občanský qákonik I. Obecná cást (\$ 1-654). Komentár. 1. vyd. Praha: C. H. Beck, 2013, s. 1773. ISBN 978-80-7400-499-5.

40 Rozhodnutí Nejvyššího soudu Československé republiky Rv I 1139/24 ze dne 06. 08. 1924. 
Použitý pojem by měl být jazykově obvyklý. ${ }^{41} \mathrm{~V}$ moderní společnosti a ve světle právní úpravy de lege ferenda ovšem nelze jazykovou obvyklost pojmu, použitého pro označení souboru jednotlivých věcí, chápat absolutně a formalisticky. Postačí, pokud takový pojem bude objektivně obvyklý v řeči pouze určité, kvantitativně a kvalitativně vymezené, skupiny osob, resp. jazykově obvyklý pro určitou oblast společnosti, a to z hlediska její působnosti (např. v určité oblasti průmyslu, techniky, stavebnictví, podnikání, apod.). $\mathrm{V}$ konkrétních prrípadech tedy bude vždy rozhodující posoudit, zda pojem, použitý pro označení souboru jednotlivých věcí, je možné objektivně, nikoli však absolutně, považovat za (jazykově) obvyklý.

\section{Hromadná věc podle dosavadní judikatury}

Podle dosavadní judikatury lze označit za věc hromadnou např. knihovnu ${ }^{42}$, sbírku poštovních známek, sklad zboží a skladové zásoby ${ }^{43}$, dále hotelové stř́bro ${ }^{44}$, nábytek za předpokladu, že tvoří účelový, stylový nebo architektonický celek ${ }^{45}$, ryby v rybníce, v sádce nebo jiném ohraničeném místě (nikoli však ryby žijící ve volně tekoucích vodách) ${ }^{46}$, vodovod ve smyslu zákona č. 274/2001 Sb., složený z vodovodního řadu a vodárenských objektư ${ }^{47}$, apod. Sklad zboží (zásoby zboží umístěné ve skladu) byl rozsudkem Nejvyššího soudu ze dne 20. 01. 2011, sp. zn. 21 Cdo 3757/2009, označen z hlediska právních vztahů za jedinou věc, bez ohledu na to, zda je či není věcí hromadnou. Ve světle současné právní úpravy a dikce ustanovení \501 ObčZ bude sklad zboží, resp. zásoby umístěné ve skladě, představovat typickou věcí hromadnou.

\section{Některá specifika věci hromadné}

Věc hromadná, díky její výslovné právní úpravě v ustanovení \ 501 ObčZ, představuje samostatný předmět právních vztahů; může být objektem jak práv obligačních, tak i věcných. Hromadná věc mohou tvořit jednotlivé věci různé kvality (věci movité, nemovité, hmotné, nehmotné, apod.). Právní jednání týkající se věci hromadné se automaticky vztahuje i na jednotlivé věci, které ji tvoří. ${ }^{48} \mathrm{~V}$ této souvislosti pak vyvstává řada otázek, týkajících

41 SEDLÁČEK, Jaromír, ROUČEK, František. Komentár k Československému obecnému qákoníku ob̌̌anskému a občanské právo platné na Slovensku a v Podkarpatské Rusi. Díl drubý (』 285 aそ̌. 530). Praha: Právnické knihkupectví a nakladatelství V. Linhart, 1935. Reprint původního vydání CODEX Bohemia, s. r. o., 1998, s. 56. ISBN 80-85963-64-7.

42 Rozsudek Nejvyššího soudu ČR ze dne 26. 06. 2012, sp. zn. 22 Cdo 1213/2012.

43 Rozhodnutí Městského soudu v Praze ze dne 01. 04. 2010, sp. zn. 177 Cm 4/2009.

44 Rozhodnutí Nejvyššího soudu Československé republiky Rv I 1139/24 ze dne 06. 08. 1924.

45 Rozsudek Nejvyššího soudu ČR ze dne 28. 02. 2006, sp. zn. 33 Odo 447/2004.

46 Usnesení Nejvyššího soudu ČR ze dne 19. 02. 2009, sp. zn. 25 Cdo 234/2007.

47 Rozsudek Nejvyššího soudu ČR ze dne 10. 12. 2009, sp. zn. 22 Cdo 944/2007.

48 Srov. TÉGL In: MELZER, Filip, TÉGL, Petr a kol. Občanský zákonik - velký komentár. Svazek III., $\int 419$ 654. Praha: Leges, 2014, s. 282. ISBN 978-80-7502-003-1. 
se napr. formy právního jednání nebo okamžiku, ke kterému nastávají účinky právního jednání (např. převodu vlastnického práva, apod.), atp. Je ovšem nad rámec tohoto příspěvku se blíže zabývat všemi v úvahu přicházejícími otázkami, resp. specifiky věci hromadné.

Obecně lze říci, že pro převod vlastnického práva k věci hromadné se uplatní pravidlo upravující převod vlastnického práva podle ustanovení \1099 ObčZ. Pokud ovšem bude věc hromadná tvořena mj. věcmi nemovitými, bude vyžadován, v souladu s ustanovením \1105 ObčZ, i zápis změny vlastnického práva k věci nemovité ve veřejném seznamu (katastru nemovitostî); stejně tak i v prrípadě věcí movitých zapisovaných do veřejných seznamů, a to v souladu s ustanovením \ 1102 ObčZ. ${ }^{49}$

Speciální úprava pro převod vlastnického práva k obchodnímu závodu, jako věci hromadné, je obsažena v ustanovení \2180 ObčZ; vlastnické právo k závodu jako celku se nabývá bud' zveřejněním údaje o uložení dokladu o koupi závodu do sbírky listin, nebo účinností smlouvy. ${ }^{50} \mathrm{Na}$ základě ustanovení \} 2 1 8 0 \text { odst. } 3 \text { ObčZ je taktéž vyža- } dován deklaratorní zápis změny vlastnického práva $\mathrm{v}$ prríslušných veřejných seznamech.

Co se týká formy pro právního jednání v případě věci hromadné, bude nutné vyjít z ustanovení \559 a násl. ObčZ. Domnívám se, že písemnou formu bude vyžadovat právní jednání, kterým se bude zřizovat, převádět nebo rušit věcné právo k věci hromadné, tvořené mj. věcí nemovitou, s ohledem na ustanovení \560 ObčZ a ustanovení \11 a \15 zákona č. 256/2013 Sb., o katastru nemovitostí (katastrální zákon) - dále jen „KatZ“.

\section{Zástavní právo $\mathrm{k}$ věci hromadné}

Diskutovanou problematikou, především v notářské praxi, je problematika zástavního práva k věci hromadné, včetně jeho zápisu do Rejstříku zástav. Obecná právní úprava zástavního práva je obsažena v ustanovení \1309 a násl. ObčZ. Občanský zákoník obsahuje speciální právní úpravu zástavního práva ve vztahu k věci hromadné. Ustanovení \1314 odst. 2 ObčZ stanoví, že pokud je zástavou hromadná věc, vyžaduje se pro zástavní smlouvu forma veřejné listiny; podle ustanovení \3026 odst. 2 ObčZ se veřejnou listinou rozumí mj. notářský zápis. Ustanovení \ 1319 odst. 2 ObčZ stanoví, že zástavní právo $\mathrm{k}$ věci hromadné vznikne zápisem do Rejstř́íku zástav; podle ustanovení \ 1319 odst. 3 ObčZ provede zápis do Rejstř́ku zástav notář, který zástavní smlouvu sepsal, bez zbytečného odkladu po jejím uzavření, nicméně s ohledem na $\int 35 \mathrm{~g}$ odst. 3 NotŘ pouze za předpokladu, že zástavní smlouva bude účinná. V opačném prrípadě notár zapíše zástavní právo k věci hromadné do Rejstříku zástav bez zbytečného odkladu až poté, co zástavní smlouva nabude účinnosti. Zásadní praktický význam mají dále ustanovení \1347 a 1348 ObčZ.

\footnotetext{
49 Srov. SPÁČIL, Jiří a kol. Občanský zákoník I. Obecná část (§ 1-654). Komentár. 1. vyd. Praha: C. H. Beck, 2013, s. 1774. ISBN 978-80-7400-499-5.

50 \2180 odst. 2 zákona č. 89/2012 Sb., občanský zákoník.
} 
V souvislosti se vznikem zástavního práva k věci hromadné, která může být tvořena jednotlivými věcmi různé kvality, vzniká otázka, zda postačí zápis zástavního práva k věci hromadné, jako celku, do Rejstř́ku zástav nebo zda se vyžaduje i zápis do veřejných seznamů, ve kterých jsou jednotlivé věci tvořící věc hromadnou evidovány (s ohledem na formální publicitu veřejných seznamů); pokud ano, tak jaké jsou účinky tohoto zápisu. Podle ustanovení \ 1319 odst. 2 ObčZ je vznik zástavního práva k věci hromadné vázán na okamžik zápisu do Rejstř́ku zástav; ustanovení \1316 ObčZ ovšem váže vznik zástavního práva $\mathrm{k}$ věci zapsané ve veřejném seznamu na okamžik jeho zápisu do tohoto seznamu. Na základě ustanovení \ 1347 ObčZ se zástavní právo k věci hromadné vztahuje i na jednotlivé věci, které k zástavě - věci hromadné náleží. Je tedy otázkou, zda vnímat jako speciální ustanovení \1319 odst. 2 ObčZ vůči ustanovení \1316 ObčZ nebo ustanovení \ 1316 ObčZ vůči ustanovení \ 1319 odst. 2 ObčZ.$^{51} \mathrm{~V}$ zásadě zde dochází ke střetu podstaty a účelu institutu věci hromadné (nakládat s jednotlivými věcmi jako s věcí jedinou) na straně jedné s principem formální publicity veřejných seznamů (\$ 980 a násl. ObčZ) na straně druhé. V tomto směru je tak právní úprava zástavní práva k věci hromadné v ObčZ nejednoznačná a v praxi mưže vést $\mathrm{k}$ rozdílné interpretaci a aplikaci zákona. Ve svém důsledku tak do právních vztahů přináší značnou právní nejistotu.

Možnými (teoretickými) př́stupy k této problematice se zabýval např. JUDr. Vymazal ${ }^{52}$ nebo JUDr. Richter ${ }^{53}$; v bližším odkazuji na jejich výklad v publikacích uvedených v poznámce pod čarou.

Osobně mám za to, že v souladu s ustanovením \1319 odst. 2 a \ 1347 ObčZ se zástavní právo k věci hromadné vztahuje na její jednotlivé věci (bez ohledu na to, zda evidují ve veřejných seznamech či nikoli) od okamžiku jeho zápisu do Rejstř́ku zástav. Za účelem naplnění principu formální publicity veřejných seznamů je následně vyžadován zápis zástavního práva i do veřejných seznamů, ve kterých jsou jednotlivé věci evidovány. Následný zápis zástavního práva do jednotlivých veřejných seznamů však nebude mít konstitutivní, ale deklaratorní (evidenčnî) účinky. ${ }^{54}$ Díky ustanovení \984 ObčZ bude chráněna i dobrá víra třetích osob (především v období mezi zápisem zástavního práva do Rejstř́ku zástav a jeho zápisem do jednotlivých veřejných seznamů), jestliže zapsaný stav ve veřejném seznamu nebude odpovídat skutečnému právnímu stavu. V opačném př́padě, pokud by se zástavní právo k věci hromadné vztahovalo na její jednotlivé věci

51 Srov. SPÁČIL, Jiří a kol. Ob̌̌anský zákoník III. Vécnápráva (I 976-1474). Komentár 1. vyd. Praha: C. H. Beck, 2013, s. 1080-1081. ISBN 978-80-7400-499-5.

52 VYMAZAL In: VYMAZAL, Lukáš. Zástavni právo v novém občanském zákoníku (zákon č. 89/2012 Sb.). Praha: Linde Praha, a. s., 2014, s. 185-188. ISBN 978-80-7201-950-2.

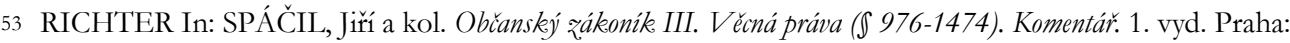
C. H. Beck, 2013, s. 1079-1081. ISBN 978-80-7400-499-5.

54 Srov. ustanovení \2180 ObčZ, podle kterého se vlastnické právo k závodu nabývá zveřejněním údaje o uložení dokladu o koupi závodu do sbírky listin; následný zápis práv k věcem podle jiných právních předpisů má pouze deklaratorní účinky. 
od okamžiku konstitutivního zápisu tohoto zástavního práva do jednotlivých veřejných seznamů, by institut věci hromadné postrádal smysl.

$\mathrm{V}$ př́padě nemovitých věcí evidovaných v katastru nemovitostí, které mj. tvoří věc hromadnou - zástavu, je možné prakticky (z důvodu právní jistoty) postupovat dvojím způsobem. První zpo̊sob koresponduje se shora uvedeným, kdy po zápisu zástavního práva k věci hromadné do Rejstř́ku zástav se následně provede deklaratorní zápis do katastru nemovitostí, a to vkladem ( $\left.\int 11 \mathrm{KatZ}\right)$ na základě souhlasného prohlášení o vzniku práva ${ }^{55}$ podle ustanovení \ 66 vyhlášky č. 357/2013 Sb., o katastru nemovitostí. ${ }^{56}$ Druhý způsob praktického řešení spočívá $\mathrm{v}$ tom, že nemovité věci evidované $\mathrm{v}$ katastru nemovitostí se zastaví samostatně před zastavením věci hromadné. Záleží totiž pouze na vưli zástavce a zástavního věritele, zda nemovité věci evidované v katastru nemovitostí budou považovat za součást věci hromadné - zástavy nebo zda je z důvodu právní jistoty zastaví samostatně před zastavením věci hromadné. Ke vzniku zástavního práva k těmto nemovitým věcem však vzhledem $\mathrm{k} \int 1348$ ObčZ musí dojít dříve, než vznikne zástavní právo k věci hromadné. $\mathrm{V}$ této souvislosti je pak dále nutné vzít v potaz i ustanovení \508 ObčZ a do katastru nemovitostí zapsat i případnou výhradu, že stroj nebo jiné upevněné zařízení není ve vlastnictví vlastníka nemovité věci evidované v katastru nemovitostí.

Rejstř́k zástav je upraven ustanovením \35f a násl. zákona č. 358/1992 Sb., notářský řád (dále jen „Noť̌"), a dále předpisem Notářské komory č. NK01/2013, o Rejstř́ku zástav (dále v textu jen „PNKoRZ“).

\section{Soubor pohledávek, coby věc hromadná}

Prezidium Notářské komory České republiky (dále jen „, Prezidium NKČR“) přijalo na svém zasedání dne 16. 07. 2104 výkladové stanovisko č. VS 3/2014 (dále jen „VS $\left.3 / 2014^{‘}\right)$, podle kterého soubor pohledávek nenaplňuje definici věci hromadné ve smyslu \501 ObčZ a zástavní právo k souboru pohledávek tedy nemůže být dle \ 1319 odst. 2 ObčZ do Rejstř́ku zástav zapsáno. S tímto závěrem Prezidia NKČR vyslovil nesouhlas např. JUDr. Tégl ${ }^{57}$ nebo JUDr. Bezouška a spol. ${ }^{58}$

Je samozřejmě možné vést rozsáhlé diskuze o tom, zda vyslovený závěr Prezidia NKČR je správný či nikoli. Nutné je si ovšem uvědomit, že Prezidium NKČR nevyloučilo mož-

55 Zástavní právo vzniklo na základě ustanovení \1319 odst. 2 ObčZ zápisem do Rejstř́ku zástav.

56 Srov. BAREŠOVÁ, Eva, BLÁHOVÁ, Iveta, DOUBEK, Pavel a kol. Katastrálni qákon. Komentár. Praha: Wolters Kluwer, a. s.,2015, s.114-115. ISBN 978-80-7478-703-4.

57 TÉGL, Petr. OBCZAN LIVE: Lze zastavit soubor pohledávek? OBCZAN - komunitní portál o rekodifkaci [online]. Publikováno 24. 04. 2015 [cit. 22. 03. 2016]. Dostupné z: https://www.obczan.cz/clanky/ obczan-live-lze-zastavit-soubor-pohledavek

58 BRUTHNAS, Martin, BÍLÝ, Václav, BEZOUŠKA, Petr. Finanční a bankovní právo. Lze zastavit soubor pohledávek? Ano! Právni aktuality PRK Partners [online]. č. 1/2015. [cit. 22. 03. 2016]. Dostupné z: http:// files.prkpartners.com/cs/ke-stazeni/pravni-aktuality/201502_legalupdate_prk.pdf 
nost, aby zástavní právo $\mathrm{k}$ souboru pohledávek, který naplňuje definici věci hromadné ve smyslu \501 ObčZ, vzniklo zápisem do Rejstríku zástav. Pokud tedy pojmové znaky \501 ObčZ naplněny budou, zástavní právo $\mathrm{k}$ souboru pohledávek, coby věci hromadné, může vzniknout zápisem do Rejstříku zástav podle \1319 odst. 2 ObčZ. Určujícím kritériem bude mj. hospodářská souvislost jednotlivých pohledávek souboru. Na druhou stranu z VS 3/2014 jednoznačně vyplývá, že ne každý soubor pohledávek je věc způsobilá k zápisu do Rejstř́ku zástav, coby věc (movitá) hromadná. Jinými slovy řečeno, zástavní právo k souboru pohledávek nemůže vzniknout zápisem do Rejstříku zástav dle \} 1 3 1 9 \text { odst. } 2 \text { ObčZ, jestliže nebude splňovat definiční znaky věci hromadné. }

\section{Soubor věcí}

ObčZ se o souboru věcí zmiňuje např. v souvislosti s postoupením souboru pohledávek; podle ustanovení $\ 1887$ ObčZ platí, že: „Postoupit lze i soubor pobledávek, at' již současných nebo budoucich, je-li takový soubor pobledávek dostatečnè určen, zejména pokud se jedná o pobledávky

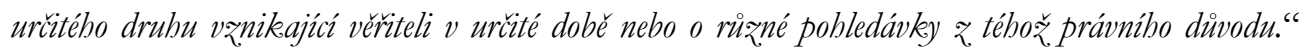
Legální definici pojmu ,soubor věcci" ovšem v současném právním řádu nenajdeme.

Soubor věcí za věc v právním smyslu, jak ji definuje ustanovení $\ 489$ Obč, považovat nelze. Soubor věcí nemůže být sám o sobě samostatným předmětem právním vztahů a je zapotřebí jej vnímat pouze jakýsi seznam, resp. soupis jednotlivých věcí. Předmětem právního jednání tak mohou být pouze jednotlivé věci souboru; tyto sledují (každá) svůj vlastní právní osud.

\section{Závěr}

Cílem tohoto př́spěvku bylo charakterizovat a vymezit pojem věci hromadné a souboru věcí, jejich vztahu a zodpovědět alespoň některé (základní a více či méně problémové) otázky, které právní úprava věci hromadné a souboru věcí, její interpretace a následné aplikace v praxi vyvolává. Je žrejmé, že v souvislosti s věcí hromadnou a souborem věcí vyvstává řada dalších ( $v$ tomto prýspěvku nezmíněných) otázek, se kterými je a bude se zapotřebí vypořádat. Jednotlivé závěry by však vždy měly sledovat účel a podstatu institutu věci hromadné a souboru věcí ve světle ObčZ. 